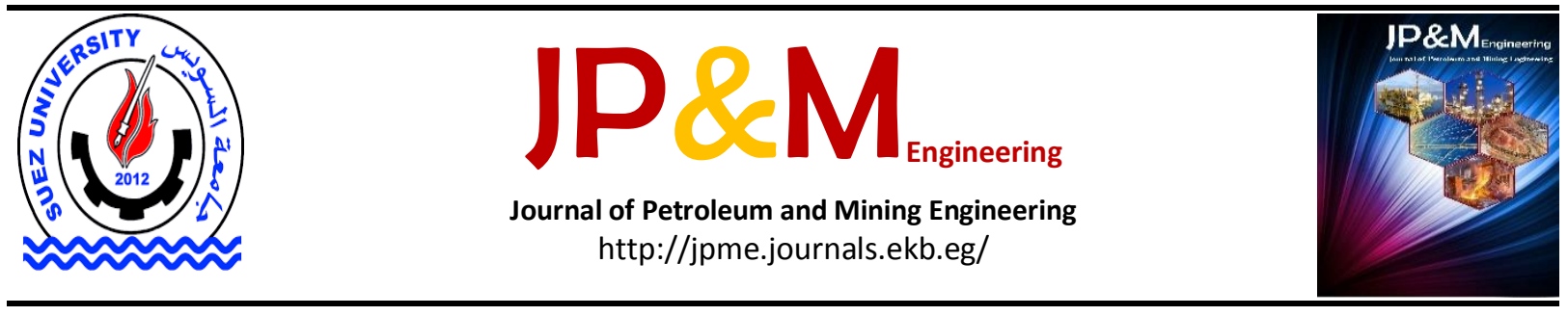

\title{
Geotechnical Evaluation of Soil at El-Alamein New City, Northern Coast, Egypt
}

\author{
Mohammed A. Karam ${ }^{1 *}$, Ahmed M. Hegazi ${ }^{2 *}$ and Tarek A. Seleem ${ }^{2 *}$ \\ ${ }^{1}$ The Arab Contractors Company. \\ 2 Suez Canal University, Faculty of Science, Geology Dept. \\ *Corresponding author e-mail: tarekseleem73@yahoo.com
}

\section{Article Info}

Received 7 Feb. 2020

Revised 12 Mar. 2020

Accepted 14 May 2020

\section{Keywords}

El-Alamein New City; geotechnical investigation Unconfined Compressive Strength; Rock Quality Designation.

\begin{abstract}
A geotechnical investigation was carried out on the soil of El-Alamein New City, northern coast. The investigation includes both in-situ and laboratory tests. The achieved results reveal that the soil profile displays different layers; these are the topmost fill layer, the sandstone layer, the upper limestone layer, the clayey layer, the middle gypsiferous limestone layer and finally the lower limestone layer. Generally, the fill layer is fine- to medium-grained sand. The sandstone layer has a relative density very loose, loose, medium to dense (SPT: 1-45 blows/ft). The upper limestone layer is moderately-weak and has strong unconfined compressive strength $\left(q_{u}: 91,326 \mathrm{~kg} / \mathrm{cm}^{2}\right.$ ) and very poor quality (R.Q.D: $\left.0-12 \%\right)$. The clayey layer is very poor, and it has a high swelling potential (PI: 16-54\%) and a high water content (31$44 \%$ ). The middle gypsiferous limestone layer ( $7.512 \mathrm{~m}$ thick) has a weak unconfined compressive strength (qu: $37-50 \mathrm{~kg} / \mathrm{cm} 2$ ) which is poor to very poor quality (R.Q.D: 15-35\%). The lower limestone layer has moderately strong unconfined compressive strength $\left(q_{u}: 114 \mathrm{~kg} / \mathrm{cm}^{2}\right.$ ) and very poor quality (R.Q.D: 0-10\%). Several lenses of kaolinite to illite composition are encountered within this layer which have very high

swelling potential.
\end{abstract}




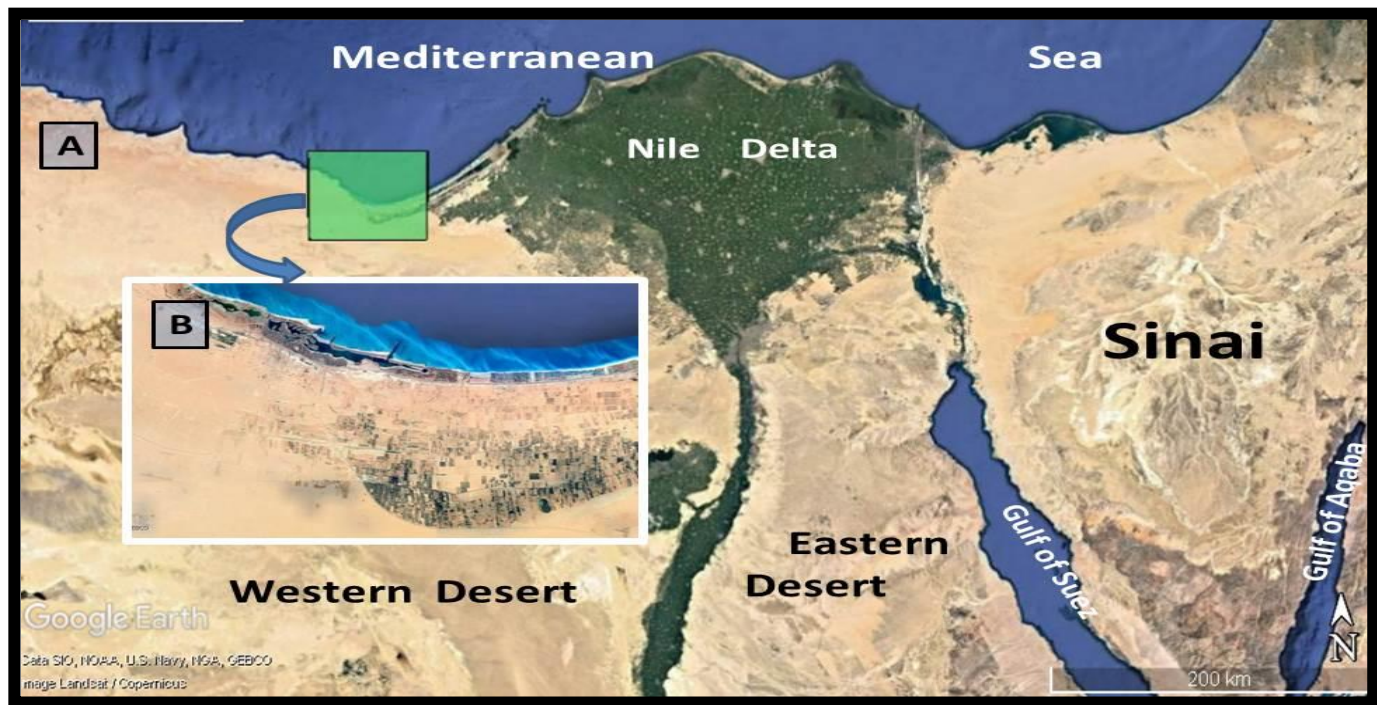

The present study aims at the assessment of the different foundation beds based on physiosoil profile. Hence, the soil suitability for the different mechanical and geotechnical investigations of the land-use aspects be measured and the purpose of

Figure 1 Google earth view of the location (A) and the study area (B).

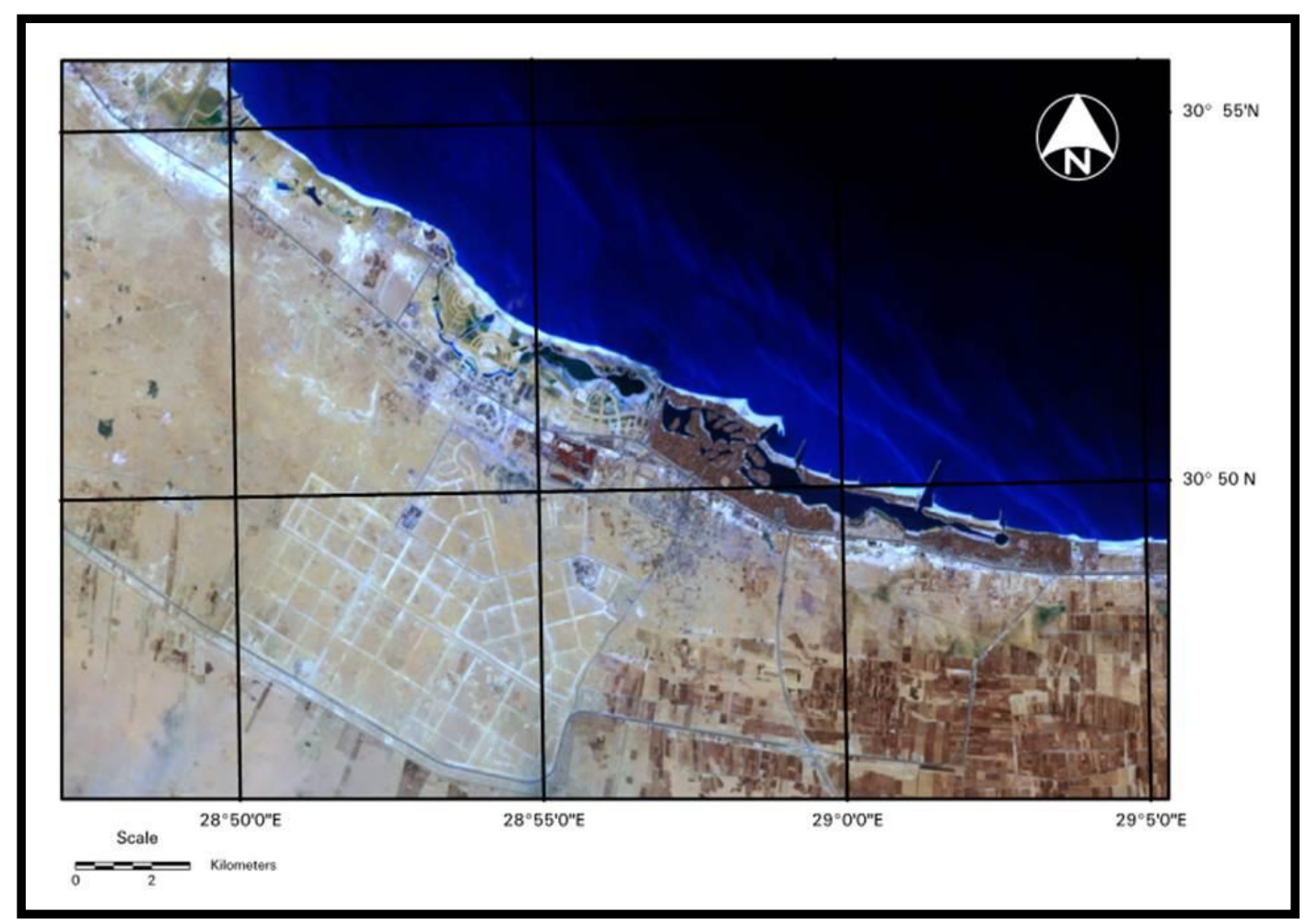

Figure 2 Landsat8 satellite image of El-Alamein area, bands 7, 4, \& 2.

urban extension can be achieved. Nevertheless, the assessment of the geotechnical properties of soils before the establishment of any giant project is vital. This enables us to be familiar with the problems that might be encountered during the implementation of the strategic development planning of El-Alamein New City.

\section{Geomorphology}

The study area encompasses two major geomorphological units; coastal plain and elevated plateau (Figs. 3, 4 \&5). The soils of the present area are highly calcareous, whereas the sub-soil layers are locally marine limestone. The soil depth varies accordingly, being thinner in the sloping plateau and thicker in the coastal plain. The soil of the study area can be divided into; the entisols and aridisols. The first type of psamments suborders, whereas the former one encompasses salids and calids suborders [1].

\section{Coastal Plain}

The coastal plain represents a land area that extends parallel to the Mediterranean coast from east to west with a tendency towards the sea. The term coastal plain refers to that part of the land which borders the seashore [2]. Some features result from the 


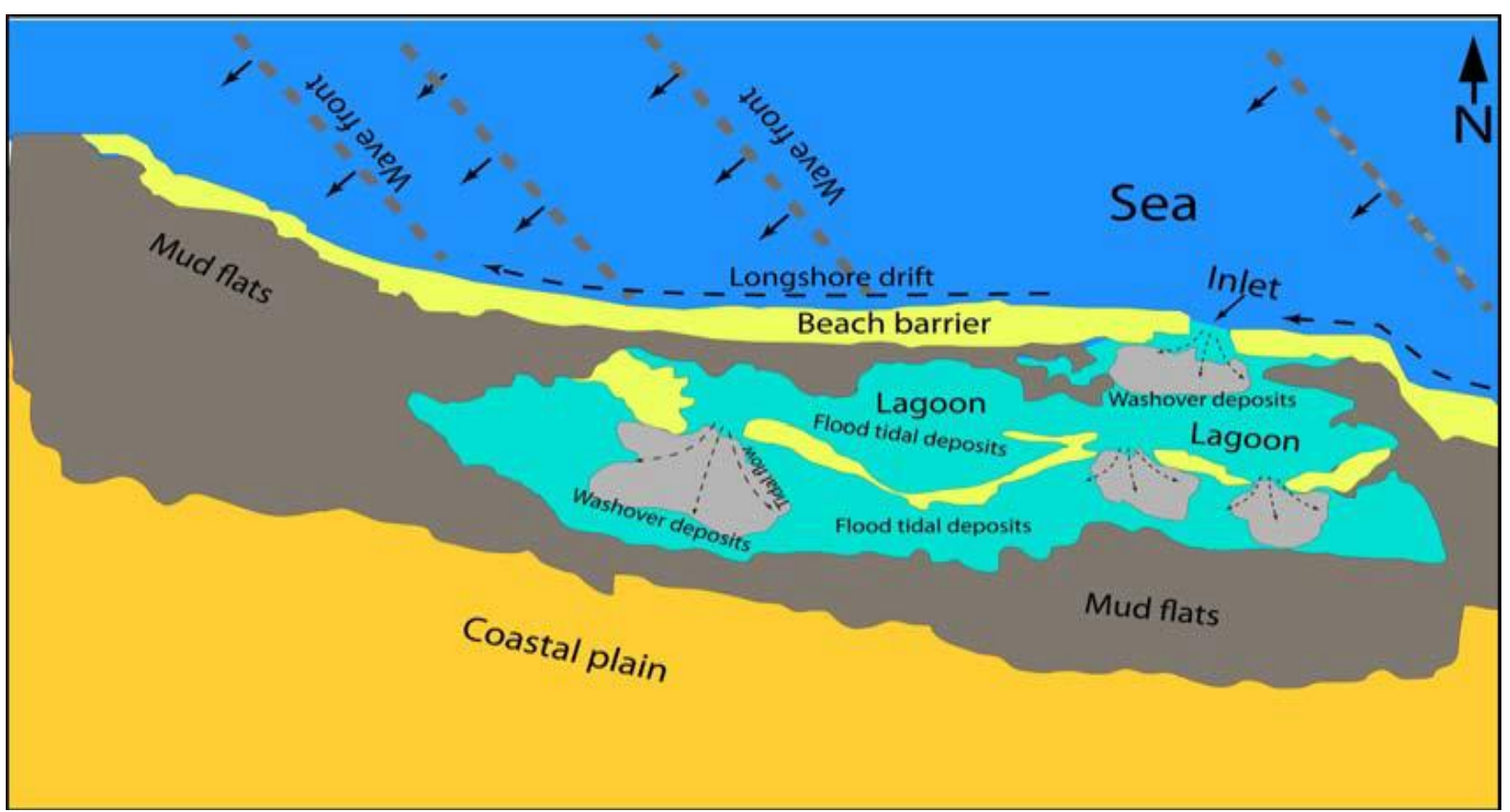

Figure 3 Geomorphologic map of the northern coast including the study area [3].
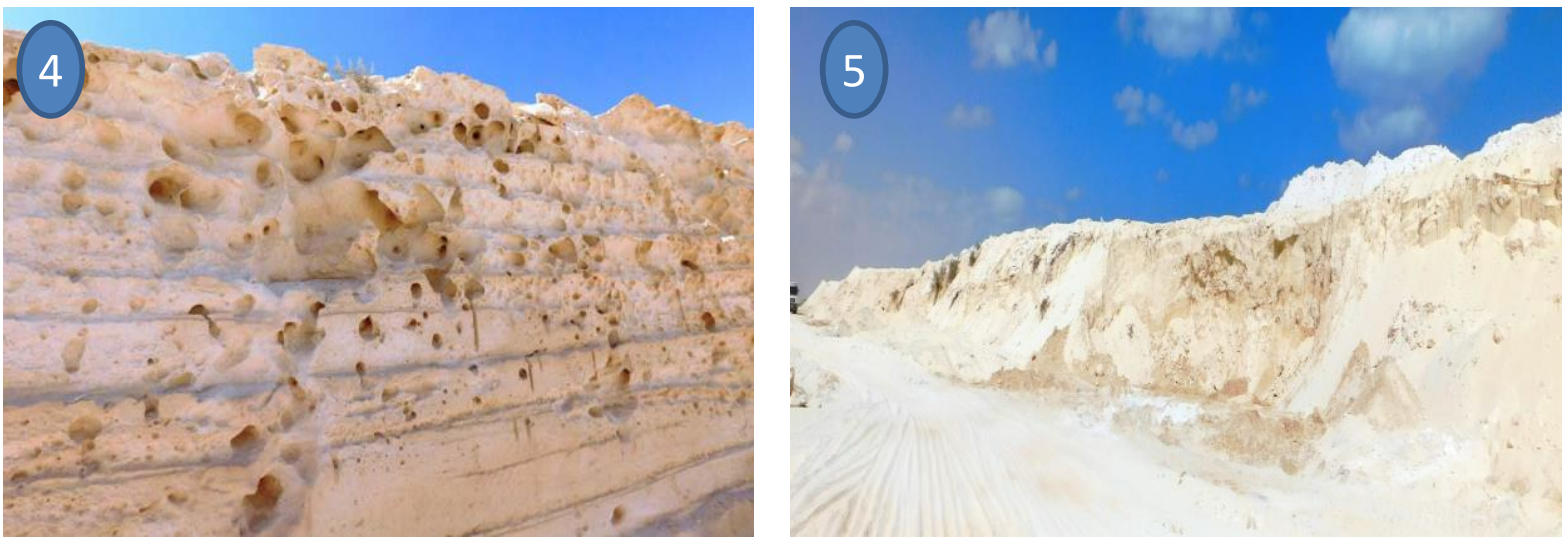

Figure 4 The cavernous nature of the carbonate units which built up the coastal plain and the bed rock of the lagoon deposits.

Figure $\mathbf{5}$ The remnant of the carbonate rocks of beach barrier.

depositional processes of the coastal plain such as beach, coastal dunes, coastal ridges, and others are resulted from erosional processes such as wave-cut platform and sea cliffs.

\section{Coastal Plain Depositional Features}

\section{Beach sediments}

These sediments occupy a narrow strip extending along the shores of the Mediterranean from east to west with and gradually leaning towards the beach.

\section{Beach dunes}

The dunes stretch parallel to the Mediterranean shore along the shore and behind the sabkha deposits and cover the top of the beach edges. They are disconnected dunes of irregular shapes and the average height is about $10 \mathrm{~m}$. They are produced from beach sediments and partly from aerated sand [4].

\section{Beach edges}

These edges extend parallel to the shores of the Mediterranean and gradually become thinner towards the shore.

\section{Coastal Depressions}

These depressions extend parallel to the Mediterranean shore between the coastal edges and are composed of valleys sedimentary. They are divided into two types; the first one is filled mainly with alluvial and lagoon deposits including carbonate sand, organic algal, and gypsum [5]. The second one compromises the low areas filled with saline water with salt deposits along its borders fringed with algal mats, marshes, and extensive silt and sandy silt sabkhas [6].

\section{Coastal Plain Erosional Features}

This type includes phenomena resulting from subversive operations of the coastal plain, which include: 
This type is a gradually-inclined surface resulting from the erosion of the wave slope of the sea: This slope also results from the erosion of the wave.

\section{Elevated Plateau}

This plateau is located in the south of the coastal plain with a height of about $250 \mathrm{~m}$ which gradually decreases at a rate of $3 \mathrm{~m} / \mathrm{km}$ to reach about $40 \mathrm{~m}$ above sea level in the northern part. Topographically, the study area is divided into four types: sandy soil, gravelly soil, clay soil, and rocky soil. The plateau consists of fissured and jointed limestone. In the elevated plateau, old shorelines disappear further south and give way to a very flat surface which is highly weathered and covered by hard pink limestone crust with detrital sediments. The calcareous loamy deposits which occasionally cover the elevated plateau are transported and deposited by water action from the elevated areas. On the eastern side of the elevated plateau, the extensive accumulations of loose sandy deposits are present which are derived essentially by wind action [7].

\section{Geographical Setting}

El-Alamein New City is a part of the corridor of Matrouh Governorate which is lying on the northern coast of Egypt, $106 \mathrm{~km}$ west of Alexandria. It lies $7 \mathrm{~m}$ above sea level with desert climate as the major part of the Middle East and North Africa. During the different periods of the year, there is virtually no rain except in January with an average of $29 \mathrm{~mm}$, whereas the annual average of precipitation is about $107 \mathrm{~mm} /$ year. New Alamein city is less hot than the rest of Egypt due to the prevailing Mediterranean winds. The temperature ranges from $18^{\circ}$ in January and $31^{\circ}$ in August with an annual average of $24.5^{\circ}$. The population is 7393 inhabitants, [8].

Spanning an area of 48,000 feddans near the Mediterranean town of El-Alamein, the New Alamein City is being built which expects to contribute to accommodating a booming population, curbing unemployment, and stimulating economic growth. New Alamein City would be a comprehensive project that includes touristic, residential, agricultural, and industrial segments. It is aimed that the construction of New Alamein is a part of the Northwest Coast Development Project, a large-scale government plan to generate economic growth, improve social and living conditions for local communities, increase infrastructure, and provide housing and job opportunities for millions of Egyptians. The first phase of this huge project will be finished during 2020 on an area of 41.000 acres with an additional 8,000 acres will be attributed to International Tourism Zone (ITZ). A further 13 kilometers along the shoreline will be designated for public beaches. With acres of available land, including grazing land; resources such as dolomite, limestone, natural gas, and crude oil; and multiple tourist attractions, such as beaches, monuments, and monasteries, the northwest coast is a prime spot for economic development. It is no doubt that roads are needed to improve the accessibility via the National Roads Project; the Egyptian government has begun renovating roads in the north coast region. Many road networks have been built which extends 500 kilometers from El Alamein to Salloum. The 135kilometer Wadi Al Natrun-Alamein road connects the Wadi Al Natrun area to Alamein. The success of the establishment of New Alamein city will motivate building many eco-city projects in Egypt that address broader global issues of climate change and sustainability.

\section{Data used and Methodology}

The present study includes drilling boreholes along with the field and laboratory tests in addition to classification procedures of soil samples extracted from boreholes sites. Four boreholes were drilled; these are: $\mathrm{BH}-01, \mathrm{BH}-02, \mathrm{BH}-41$, and $\mathrm{BH}-42$. For simplicity and similarity, to a great extent, between the four ones, only one borehole of $\mathrm{BH}-01$ will be used as an example in the present study and comparison with the other three boreholes will be carried out when there is a significant difference in geotechnical parameters.

These boreholes were drilled using a rotary drilling rig (Fig. 6), which is a standard method in geothermal drilling where a string of drill pipe is hung from a derrick and turned by an engine a diesel. The rotary bit remains in strong contact with the bottom of the drilling, and is carried by hollow punching pipes that are managed with a suitable combination rotating head. Outside, the liquid is generally made of water and bentonite.

Sampling is considered one of the most important stages of geotechnical work, so it is necessary to be careful and cautious when taking and filling them to be representative of the nature of the original soil. Samples are taken in loose and coherent soil, either disturbed sample or undisturbed sample, or from Stockpiles, soil storage areas are as follows: Cohesionless Soil Sampling, Disturbed Sampling, Undisturbed Sampling, Stockpiles Sampling, Rock Sampling (Fig. 7)

The samples were filled immediately after obtaining them with closed plastic containers or in plastic bags, and then put them inside bags of fabric. The sample must fill the container as possible, and if the samples are of continuous types, such as rock samples, they were preserved in cans with divisions of appropriate diameters, so that they were held without pressure. In the case of extraction of undiminished samples, they were protected by appropriate methods from drought or from changing their size or sliding in the container. For samples that were taken from the soil Knit, the piece is in the form of a core.

The samples were covered well with one or more layers of wax, and each sample was placed separately in an outer covering that has the same dimensions of wood or the like to protect during transport. 

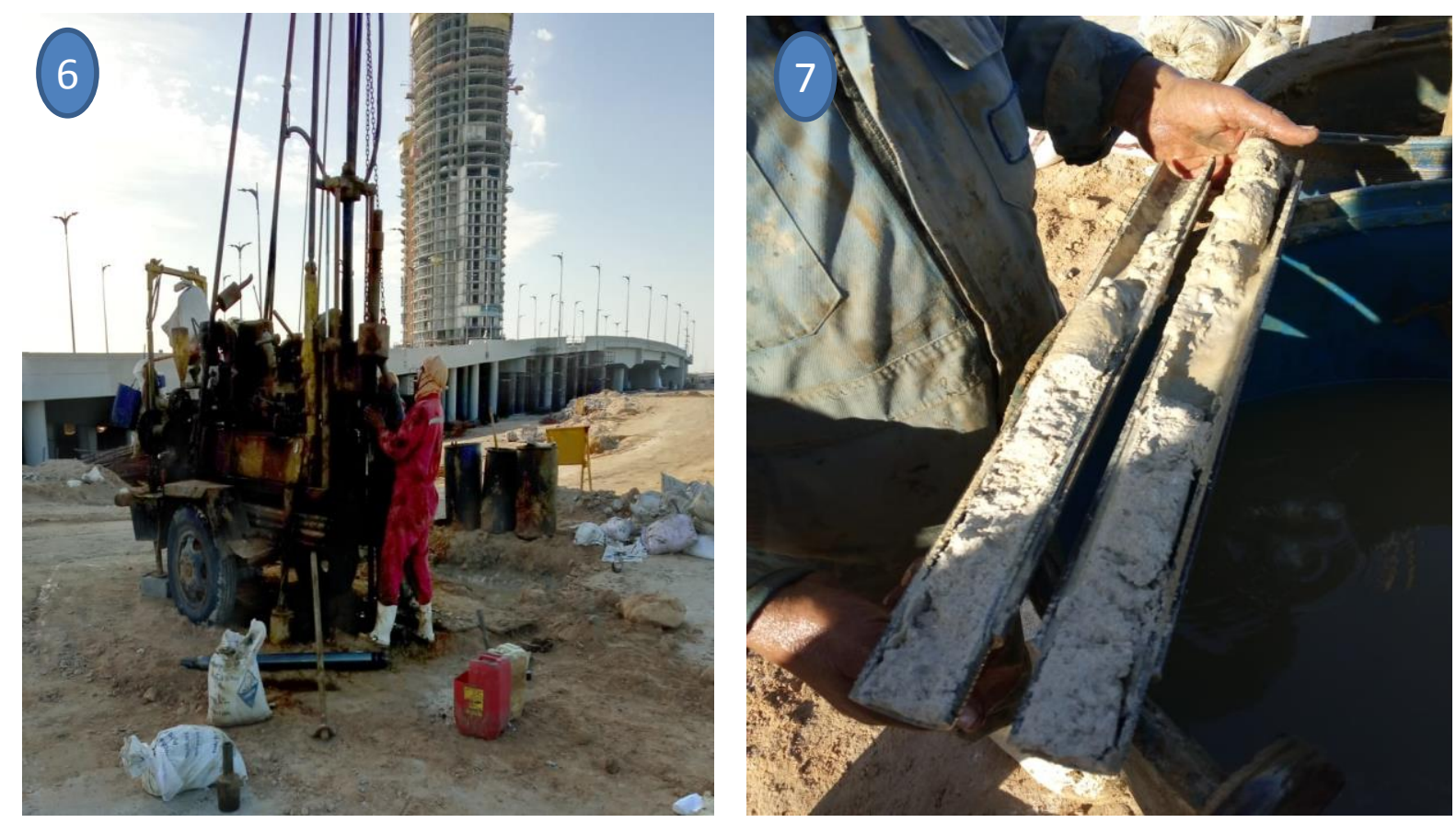

Figure 6 The Rotary drilling rig used for extraction of SPT samples shown in Figure 7.

The samples were placed in wooden shelves designated for this purpose, to ensure that they were placed in a vertical position and not moved during transportation, and they remain in this position until they are received by the lab technicians, and the samples were also protected from sunlight and high temperature, as well as from freezing and also protected during transportation from vibrations and the breakdown of sample containers.

The testing program includes both in-situ and laboratory tests; these are as follows: Standard Penetration Test (SPT) according to [9], Moisture Content according to [10], Atterberg Limits according to [11] which includes liquid limit (LL), plastic limit (PL) and shrinkage limit test of soil [12].

\section{Results and Discussion}

As an example, the results of the in situ and laboratory tests, which have been carried out at borehole $\mathrm{BH}-01$, are listed in Table (1) whereas the geotechnical section of the four boreholes is shown in Figure (8). Generally, the groundwater level at the studied site is shallow, where its depth ranges from 0.25 to $1 \mathrm{~m}$. The subsurface soil profile at the studied site displays six basic layers; these are the topmost fill layer, followed by the sandstone layer, the upper limestone layer, the clayey layer, the middle gypsiferous limestone layer, and the lower limestone layer. The detailed description of the subsurface soil profile is discussed as follows:

\section{Fill layer}

The fill layer is encountered in boreholes B4-41 and B4-42, while it's not recorded in boreholes B4-01 and B4-02. Generally, this layer has a thickness of about $1.5 \mathrm{~m}$ which consists of fine-grained to medium sand.
It has yellowish-brown color and sometimes it becomes gravelly and limy.

\section{Sand layer}

Concerning the sand layer (B) itself, it has a relative density which ranging from very loose to medium. The SPT values range from 1 to 45 blows/ft and displaying an increase with depth, where it reaches a value of 19 blows/ft at a depth of $6 \mathrm{~m}$ in $\mathrm{BH} 4-01$. Based on these SPT values, the sand layer (B) is considered a dense soil and has an angle of shear resistance $36^{\circ}-41^{\circ}$ (Table 2 ).

It's worth to mention that this layer exhibits very low SPT at a depth of about $6-9 \mathrm{~m}$, where it becomes fractured and cavernous, and loosing of drilling fluid has taken place. The Rock Quality Designations (R.Q.D) are variable, where a range of $0-27 \%$ is recorded (Table 3 ). Variability could be attributed to the nature of the soil constituents, low value is recorded when the layer is of silty or clayey nature, whereas high value is recorded when the layer becomes pure sand especially at its base.

The sand layer is underlain by three conspicuous limestone layers, the upper one is encountered is barren of clay lenses. The middle one is gypsiferous, where several gypsum lenses are encountered. The lower limestone layer is characterized by the presence of abundant clayey lenses. In addition to a clayey layer which is separating the upper limestone layer from the middle limestone layer. The detailed description of all layers is as follows: 
Table 1 The results of in situ and laboratory test of $\mathrm{BH}-01$

\begin{tabular}{|c|c|c|c|c|c|c|c|c|c|c|c|c|}
\hline Layer & Sample No & $\begin{array}{c}\text { Depth } \\
\text { (m) }\end{array}$ & $\begin{array}{l}\text { REC } \\
(\%)\end{array}$ & $\begin{array}{c}\text { RQD } \\
(\%)\end{array}$ & \multicolumn{2}{|c|}{ SPT (blows/cm) } & $\begin{array}{c}q_{u} \\
\left(\mathrm{~kg} / \mathrm{cm}^{2}\right)\end{array}$ & $\begin{array}{c}\text { Bulk } \\
\text { density } \\
\left(\mathrm{t} / \mathrm{m}^{3}\right)\end{array}$ & W \% & LL\% & PL\% & SL\% \\
\hline $\mathrm{DS}(1.5 \mathrm{~m})$ & 1 & 1.5 & & & & & & & & & & \\
\hline \multirow{4}{*}{$\begin{array}{l}\text { Fine Sand } \\
\text { layer }(4.5 \mathrm{~m})\end{array}$} & 2 & 3 & & & 5 & 30 & & & & & & \\
\hline & 3 & 4.5 & & & 11 & 30 & & & & & & \\
\hline & 4 & 6 & & & 13 & 30 & & & & & & \\
\hline & 5 & 7.5 & & & 19 & 30 & & & & & & \\
\hline \multirow{5}{*}{$\begin{array}{l}\text { Limestone } \\
(6 \mathrm{~m})\end{array}$} & 6 & 9 & 20 & 10 & & & 91 & 2.31 & & & & \\
\hline & 7 & 10.5 & 20 & 0 & & & & & & & & \\
\hline & 8 & 12 & 20 & 0 & & & & 2.22 & & & & \\
\hline & 9 & 13.5 & 20 & 0 & & & & & & & & \\
\hline & 10 & 15 & 20 & 0 & & & & & & & & \\
\hline \multirow{5}{*}{$\begin{array}{l}\text { Clay lens } \\
(5.25 \mathrm{~m})\end{array}$} & 11 & 15.75 & & & & & & & & \multirow{5}{*}{44} & \multirow{5}{*}{28} & \multirow{5}{*}{16} \\
\hline & 12 & 16.5 & & & & & & & 32 & & & \\
\hline & 13 & 18 & & & & & & & 33 & & & \\
\hline & 14 & 19.5 & & & & & & & 34 & & & \\
\hline & 15 & 21 & & & & & & & 31 & & & \\
\hline \multirow{2}{*}{$\begin{array}{l}\text { Limestone } \\
(3 \mathrm{~m})\end{array}$} & 16 & 22.5 & & & & & & & & & & \\
\hline & 17 & 24 & & & & & & & & & & \\
\hline \multirow{2}{*}{$\begin{array}{c}\text { Gypsum lens } \\
(2.25 \mathrm{~m})\end{array}$} & 18 & 25 & 25 & 0 & & & & 1.76 & & & & \\
\hline & 19 & 26.25 & 25 & 0 & & & & & & & & \\
\hline $\begin{array}{c}\text { Limestone } \\
(0.75 \mathrm{~m})\end{array}$ & 20 & 27 & & & & & & & & & & \\
\hline $\begin{array}{c}\text { Gypsum lens } \\
(1.5 \mathrm{~m})\end{array}$ & 21 & 28.5 & 25 & 0 & & & & 2.0 & & & & \\
\hline \multirow{2}{*}{$\begin{array}{c}\text { Limestone } \\
(3 \mathrm{~m})\end{array}$} & 22 & 30 & 35 & 0 & & & & 2.12 & & & & \\
\hline & 23 & 31.5 & 15 & 0 & & & & & & & & \\
\hline \multirow{2}{*}{$\begin{array}{c}\text { Gypsum lens } \\
(2.25 \mathrm{~m})\end{array}$} & 24 & 33 & 30 & 0 & & & & & & & & \\
\hline & 25 & 33.75 & 20 & 0 & & & & & & & & \\
\hline \multirow{5}{*}{$\begin{array}{l}\text { Clay lens } \\
(6.25 \mathrm{~m})\end{array}$} & 26 & 34.5 & & & & & $>4$ & 1.97 & 29 & 81 & 35 & 18 \\
\hline & 27 & 36 & & & & & 3.7 & 1.96 & 32 & & & \\
\hline & 28 & 37.5 & & & & & & & 26 & & & \\
\hline & 29 & 39 & & & & & $>4$ & 1.99 & 24 & & & \\
\hline & 30 & 40 & & & & & $>4$ & 1.98 & 25 & & & \\
\hline
\end{tabular}

Table 2 The correlation of standard penetration resistance with relative density for sandy soils [13]. Penetration Resistance (Blows/ft)

\begin{tabular}{|c|c|c|}
\hline $\begin{array}{c}\text { Penetration Resistance } \\
\text { (Blows/ft) }\end{array}$ & Relative density & $\begin{array}{c}\text { Angle of shear resistance } \\
\text { (Degree) }\end{array}$ \\
\hline$<4$ & Very loose & $28.5^{\circ}$ \\
\hline $4-10$ & loose & $28.5^{\circ}-30$ \\
\hline $10-30$ & Medium & $30^{\circ}-36^{\circ}$ \\
\hline $30-50$ & Dense & $36^{\circ}-41^{\circ}$ \\
\hline$>50$ & Very Dense & $>41^{\circ}$ \\
\hline
\end{tabular}

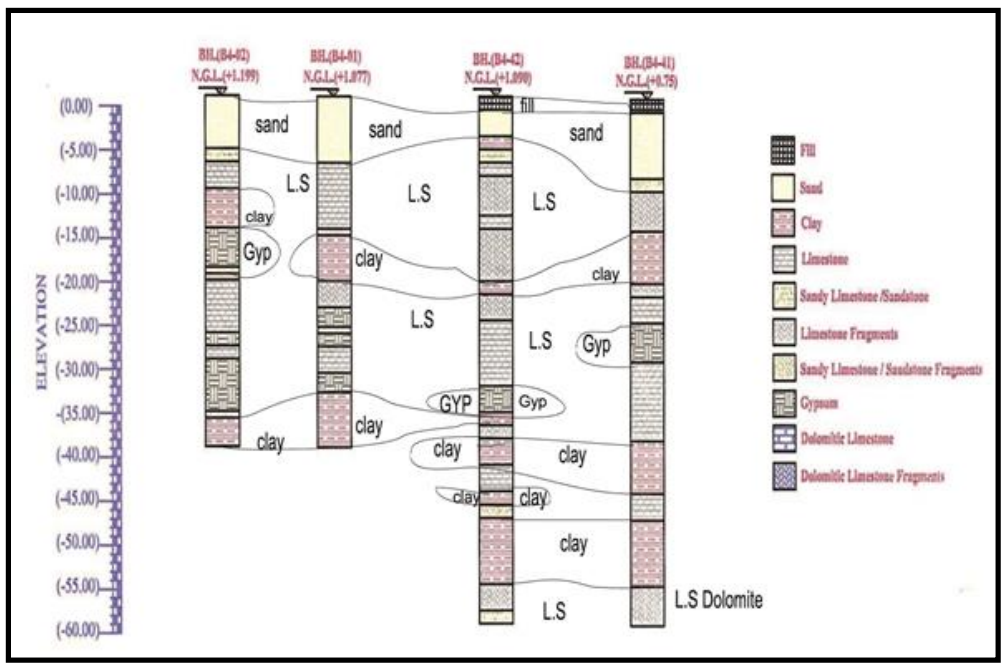

Figure 8 Geotechnical section of the four boreholes of the study area. 


\section{The upper limestone layer}

The upper limestone layer is dark brown, mediumgrained in texture, fractured and contains several cavities. It is underlain by clayey layer at a depth of $15-21 \mathrm{~m}$. This limestone layer is encountered at a depth of about $7.5 \mathrm{~m}$ and has a thickness ranges from 3 to $13.5 \mathrm{~m}$. The layer is, to some extent, is empty of clay lenses except one lens at a depth of $10.5 \mathrm{~m}$ (in B4-02).

The most conspicuous geotechnical property of this clay lens ( $4.5 \mathrm{~m}$ thick) is that the water content is very high where it reaches $40 \%$, and the liquid limit (58\%), the plastic limit (29), which is comparable to kaolinite (Table 4). Moreover, the plasticity index (PI) reaches $29 \%$, hence this type of clay is considered to have high swelling potential (Table 5). On the other hand, the unconfined compressive strength values $\left(q_{u}\right)$ range from 0.8 to $1.4 \mathrm{~kg} / \mathrm{cm}^{2}$ which are considered to be stiff (Table 6).

Concerning the upper limestone layer, the Rock Quality Designations (R.Q.D) varies between 0 and $12 \%$ which is very poor quality and has to be taken into consideration during the establishment of any foundations.

\section{The Clayey layer}

A clayey layer of variable colors is found at the base of the upper limestone layer at depth ranges from 15 to $21 \mathrm{~m}$ and has a thickness ranges from 0.75 to $6 \mathrm{~m}$. The water content ranges from 31 to $44 \%$ and the high values are recorded in B4-41. The SPT ranges from 30 to 45 blows/ft which is considered hard soil. The plasticity index (PI) in B4-01 equals $16 \%$ indicating low swelling potential, whereas it reaches $25 \%$ in B4-41 indicating high swelling potential. Based on LL (44-51\%) and PL (26-28\%) this type of clay is very poor kaolinite (Fig. 9).

\section{The middle limestone layer}

The most common characteristics of this layer is its gypsiferous nature, where several gypsum lenses are encountered at different depths and have variable thicknesses.

The middle limestone layer is found at depth ranges from 21 to $22.5 \mathrm{~m}$ and has a thickness ranges from $7.512 \mathrm{~m}$. This layer is stiff, dark brown, mediumgrained in texture, fractured and contains several cavities.

The Rock Quality Designations (R.Q.D) varies between zero and $27 \%$ which is poor to very poor quality and has to be taken into consideration during the establishment of any foundations. The unconfined compressive strength $\left(q_{\mathrm{u}}\right)$ values between 49 and $240 \mathrm{~kg} / \mathrm{cm}^{2}$ which is considered to be hard.

The gypsum lenses are found at variable depths and have a variable thickness, one of these lenses is encountered at a depth $25 \mathrm{~m}$ in B4-01 which has very poor quality (RQD $=25 \%)$. Another one is encountered $28.5 \mathrm{~m}$ in both of $\mathrm{B} 4-02$ and $\mathrm{B} 4-02$ which has very poor quality $(R Q D=10 \%)$.
The third lens of very poor quality (RQD $=0-10 \%$ ) is present in B4-02 at a depth of $28.5 \mathrm{~m}$ and has a considerable thickness that reaches $4.5 \mathrm{~m}$. A fourth lens is found in B4-01, B4-02 and B4-42 at depth ranges from 30 to $33 \mathrm{~m}$ and thickness varies between 3 and $6 \mathrm{~m}$. This lens has poor quality (RQD $=23-40 \%$ ), stiff to very stiff consistency and hard nature $\left(q_{u}=45\right.$ $50 \mathrm{~kg} / \mathrm{cm}^{2}$ ).

\section{The lower limestone layer}

This layer is encountered at a depth ranges between 37.5 and $45 \mathrm{~m}$ and has a thickness of about $7.5 \mathrm{~m}$. This layer is dark brown, medium-grained in texture, fractured and contains several cavities. This limestone is considered to be stiff and based on the Rock Quality Designations (R.Q.D) it is considered to have very poor quality.

The layer is characterized by the presence of clayey lenses of considerable thickness. The first clayey lens is encountered at depth ranges from 33.75 to $36 \mathrm{~m}$ and has a thickness ranges from 1.5 to $6.25 \mathrm{~m}$. The water content ranges from 25 to $36 \%$, and increase to $40 \%$ in B4-42. Based on LL (81-82\%), PL (35-36\%) and $\mathrm{PI}(46 \%)$ this type of clay has very high swelling potential kaolinite (Fig. 10).

The second clayey lens is encountered only at a depth of 39m in B4-42 and B4-41 and has a thickness ranges from 3 to $6 \mathrm{~m}$. The water content ranges from 23 to $26 \%$, and based on LL (92-101\%), PL (38-40\%) and PI (61-54\%) this type of clay has very high swelling potential illite.

The third clayey lens is encountered only at a depth of $39 \mathrm{~m}$ in B4-42 and B4-41 and has a thickness ranges from 3 to $6 \mathrm{~m}$. The water content ranges from 23 to $26 \%$, and based on LL (92-101\%), PL (38-40\%) and $\mathrm{PI}(61-54 \%)$ this type of clay has very high swelling potential illite.

\section{Conclusions}

The present study aimed at the geotechnical evaluation of El-Alamein new city. This evaluation included both field and laboratory tests. The results showed that the soil is heterogonous and variable in composition which affect to a great extent the properties of soil for construction purposes, in particular, the weak gypsum layer which attains a thickness ranging from 1.5 to $13.5 \mathrm{~m}$, presence of clay layers in addition to the existence of smuggling of drilling fluid with all the boreholes during drilling at different depths, cavities of different depths. All the previously mentioned factors affect the stability of the foundation layers, where this effect increases with increasing the seepage of water and the weak unconfined compressive strength of soil so it is recommended that the construction activities should be based on piles supporting foundation due to the large number of towers which are planned to be established. 
Table 3 The categories of Rock Quality Designation (RQD) [14] (Deere, 1968)

\begin{tabular}{|c|c|}
\hline Rock Quality Designation (RQD) & Category of Rock Quality \\
\hline $0-25 \%$ & Very Poor \\
\hline $25-50 \%$ & Poor \\
\hline $50-75 \%$ & Fair \\
\hline $75-90 \%$ & Good \\
\hline $90-100 \%$ & Excellent \\
\hline
\end{tabular}

Table 4 Typical values of liquid limit, plastic limit and activity of some clay minerals [12].

\begin{tabular}{|l|c|c|c|}
\hline \multicolumn{1}{|c|}{ Mineral } & Liquid Limit, LL & Plastic Limit, PL & Activity, A \\
\hline Kaolinite & $35-100$ & $20-40$ & $0.3-0.5$ \\
\hline Illite & $60-120$ & $35-60$ & $0.5-1.2$ \\
\hline Montmorillonite & $100-900$ & $50-100$ & $1.5-7.0$ \\
\hline Halloysite (hydrated) & $50-70$ & $40-60$ & $0.1-0.2$ \\
\hline Halloysite (dehydrated) & $40-55$ & $30-45$ & $0.4-0.6$ \\
\hline Attapulgite & $150-250$ & $100-125$ & $0.4-1.3$ \\
\hline Allophane & $200-250$ & $120-150$ & $0.4-1.3$ \\
\hline
\end{tabular}

Table 5 Swelling potential of soil based on Atterberg Limits [15].

\begin{tabular}{|c|c|c|c|c|}
\hline $\mathrm{PI}(\%)$ & $<2 \mu \mathrm{m}(\%)$ & $<74 \mu \mathrm{m}(\%)$ & LL & Swelling Potential \\
\hline$>35$ & $>95$ & $>95$ & $>60$ & Very high \\
\hline $22-35$ & $60-95$ & $60-95$ & $40-60$ & High \\
\hline $18-22$ & $30-60$ & $30-60$ & $30-40$ & Moderate \\
\hline$<18$ & $<30$ & $<30$ & $<30$ & Low \\
\hline
\end{tabular}

Table 6 The correlation of standard penetration resistance with unconfined compressive strength for clayey soils [13].

\begin{tabular}{|c|c|c|}
\hline $\begin{array}{c}\text { Penetration Resistance } \\
\text { (Blows/ft) }\end{array}$ & Consistency & $\begin{array}{c}\text { Unconfined compressive strength } \\
\left(\mathbf{q}_{\mathbf{u}}\right) \\
\left(\mathbf{k g} / \mathbf{c m}^{\mathbf{2}} \mathbf{)}\right.\end{array}$ \\
\hline$<2$ & Very soft & $<0.25$ \\
\hline $2-4$ & Soft & $0.25-0.50$ \\
\hline $4-8$ & Medium & $0.50-1$ \\
\hline $8-15$ & Stiff & $1-2$ \\
\hline $15-30$ & Very stiff & $2-4$ \\
\hline$>30$ & Hard & $>4$ \\
\hline
\end{tabular}

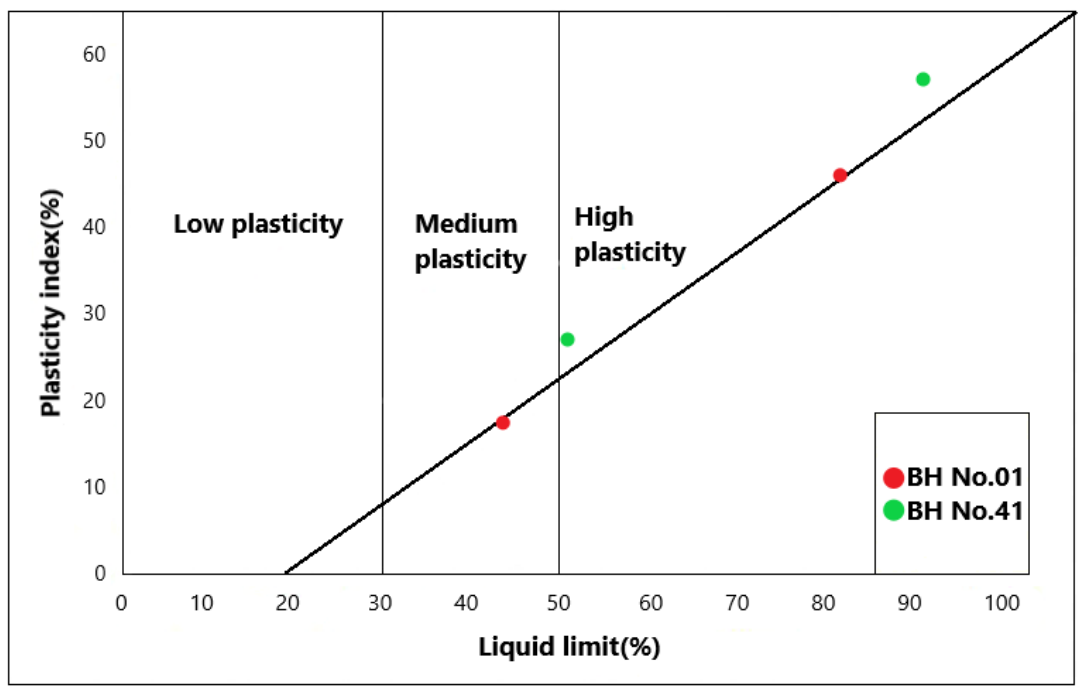

Figure 9 The Plasticity Chart of the clayey layer. 


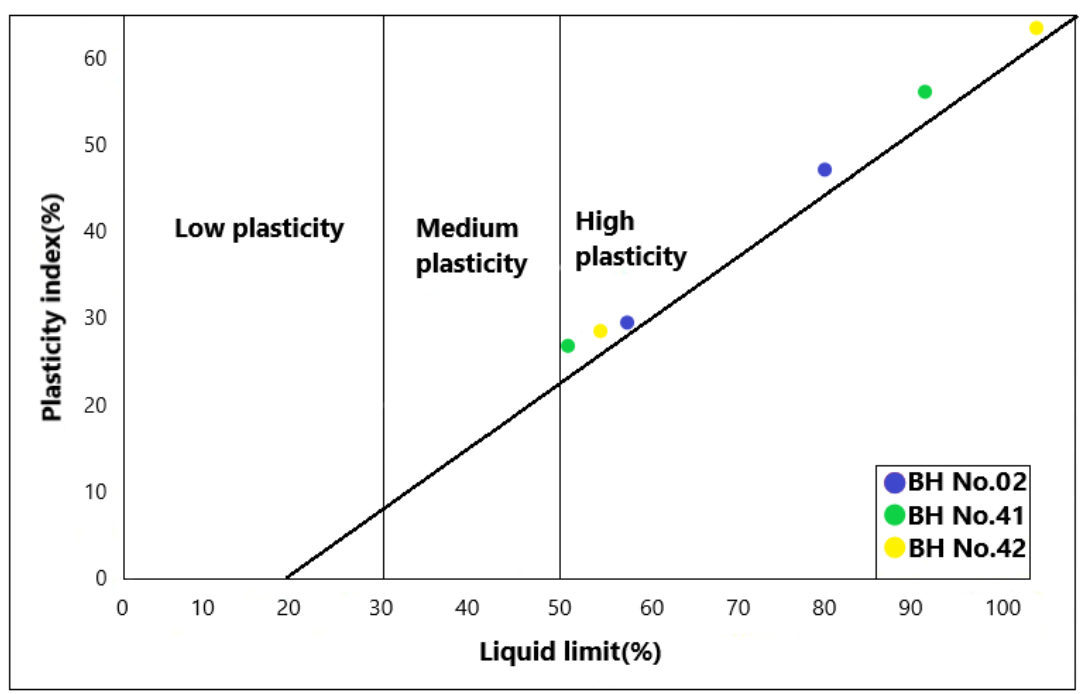

Figure $\mathbf{1 0}$ The Plasticity Chart of the clayey lenses in the lower limestone layer.

\section{Conflict of Interest}

There is no conflict of interest to declare

\section{Funding sources}

This research received no external funding.

\section{References}

[1] A.S. Sayed, Evaluation of the land resources for agricultural development- case study: ElHammam Canal and its extension, NW Coast of Egypt. Ph.D. Thesis, Hamburg Univ., Germany, 2013.

[2] I. El-Shami, M. El Shazly, A. Shata, Contribution to the geology of El- Dabaa area (Western Mediterranean litoral Zone) Part I, II. Geomorphology and Morphology, Stratigraphy and Geological structure: Bull. Inst. Desert Egypt. 19 (1): (1969) 63-96.

[3] Sofratome Group, El-Dabaa Nuclear power plant Authority (NPPA), step 5, Report chap2 and 3, Ministry of Electricity and Energy, Cairo, Egypt, 1984.

[4] R. Abu El-Ella, Geological and hydrogeological studies for El-Dabaa nuclear power plant station, North Western Desert, Egypt. M.Sc. thesis, Fac. Sic, Geology Dept. Cairo University, Egypt, 1987.

[5] Y.A. Ali, Mineralogical, geochemical and sedimentological studies on recent sabkha sediments west of Alexandria, Egypt and some upper Jurassic evaporite from Dorset, England. Ph.D. Thesis, Fac. Sci., Geology Dept Ain Shams University, Egypt, 1981.

[6] A.F. Osman, Geological, mineralogical and geochemical studies on recent lagoonal sediments from the Mediterranean Coastal Zone of Egypt, west of Alexandria, El-Alamein area. M.Sc. Thesis, Fac. Sci, Geology Dept, Ain Shams University, Cairo, Egypt, 1986.

[7] M.L. Abd El-Khalek, Hydrochemical and environmental study on the ground water of El-Dabaa area, Northern Western Coastal Zone of Egypt. M.Sc., Thesis, Fac. Sci, Geology Dept. Ain Shams University, Cairo, Egypt, 1992.

[8] Climate Data Organization. http://climatedata.org./, 2013 (accessed 13 August 2019).

[9] ASTM, D1586-11.Annual book of ASTM Standard Test Method for Standard Penetration Test (SPT) and Split-Barrel Sampling of Soils.

[10]ASTM, D2216-10. Annual book of ASTM Standard Test Methods for Laboratory Determination of Water (Moisture) Content of Soil and Rock by Mass, 2010.

[11]ASTM D4318-17. Annual book of ASTM Standard Test Methods for Liquid Limit, Plastic Limit, and Plasticity Index of Soils, 2017.

[12]B.M. Das, Principles of Geotechnical Engineering, seventh ed., Cengage Learning Publisher, USA, 2010.

[13]K. Terzaghi, R. B. Peck, Soil mechanics in Engineering Practice. Second ed., Wiley, New York, 1967.

[14]D.U. Deere, Geological Considerations, Rock Mechanics in Engineering Practice, ed. R. G. Stagg and D. C. Zienkiewicz, Wiley, New York, 1968.

[15] Y. Millogo, M. Hajjaji, R. Ouedraogo, M. Gomina, Cement-lateritic gravels mixtures: Microstructure and physical properties of lime-clayey adobe bricks Construction and Building Materials, 22 (2008a) 2386-2392. 